\title{
Intermittent Treatment of Febrile Convulsions with Nitrazepam
}

\author{
Michel Vanasse, Pierre Masson, Guy Geoffroy, Albert Larbrisseau and Pierre C. David
}

\begin{abstract}
Intermittent oral or rectal administration of diazepam for the prophylactic treatment of febrile convulsions has given results comparable to the continuous use of phenobarbital while limiting side effects and risks of toxicity. Since we believe that nitrazepam is a better anticonvulsant than diazepam, we performed a study to evaluate the effectiveness of this medication in the prophylactic treatment of febrile convulsions. Nitrazepam was given only when the children had fever and almost exclusively in children with a high risk of recurrence (less than 12 months of age at first convulsion; atypical convulsion; one or several previous convulsions). Thirty one children with a high risk of recurrence received nitrazepam. The rate of recurrence in this group was $19.3 \%$ after a follow-up of 16 months, compared to $45.8 \%$ in 24 children who also had a high risk of recurrence but in whom the parents refused the medication or gave it inadequately $(\mathrm{p}<0.05)$. Fifty one children with a low risk of recurrence also were evaluated and followed for at least 12 months (mean 15.4 months). Six were treated with nitrazepam, mostly because of parental anxiety, and none had a recurrence; of the 45 untreated children in this group, $6(13.6 \%)$ had another convulsion. These results show the efficiency of nitrazepam in the prophylactic treatment of febrile convulsions.
\end{abstract}

RÉSUMÉ: L'utilisation intermittente du diazépam par voie orale ou rectale pour le traitement prophylactique des convulsions fébriles a donné d'aussi bons résultats que l'utilisation continue du phénobarbital. Cette approche est d'autant plus intéressante qu'elle limite au minimum les effets secondaires et les risques de toxicité dus à la médication. D'après notre expérience, nous croyons que le nitrazépam est un meilleur anticonvulsivant que le diazépam et nous avons procédé à une étude visant à évaluer l'efficacité de ce médicament pour le traitement préventif des convulsions fébriles. Le nitrazépam a été donné lors des poussées fébriles et quasi exclusivement chez des enfants présentant un haut risque de récidive (âgés de 12 mois et moins; ayant présenté une convulsion fébrile atypique ou ayant présenté précédemment au moins un autre épisode de convulsion fébrile). Trente et un enfants à haut risque de récidive ont reçu cette médication et le taux de récidive a été de $19.3 \%$ après 16 mois. Chez 24 enfants présentant aussi un risque de récidive élevé et dont les parents ont refusé la médication, ou ne l'ont pas donné de façon adéquate, le taux de récidive a été de $45.8 \%$ $(\mathrm{p}<0.05)$. Cinquante et un enfants présentant un faible risque de récidive ont été suivis pour une période minimum de 12 mois (en moyenne 15.4 mois). Six d'entre eux ont été traités avec du nitrazépam, surtout à cause de l'anxiété des parents, et aucun n'a présenté de récidive; des 45 autres enfants non traités, 6 (13.6\%) ont eu une nouvelle convulsion. Ces résultats démontrent l'efficacité du nitrazépam dans le traitement préventif des convulsions fébriles.

Can. J. Neurol. Sci. 1984; 11:377-379

Clinical and animal studies (Aicardi and Chevrie, 1976; Falconer, 1976; Lennox-Buchtal, 1974; Moshé, 1981; SchiotzChristensen and Brohn, 1973; Vanucci, 1981; Wallace and Cull, 1979) suggest that febrile seizures could produce significant brain damage resulting in mental retardation and/or epilepsy. Most of these studies have been criticized because of inadequate methodology (Hauser, 1981; Vanucci, 1981) and from the present evidence, it is clear that the risk of brain damage due to febrile seizures is low (Ellenberg and Nelson, 1978; Kendig et al., 1981). If such a risk exists, it should be increased by the repetition of febrile convulsions so that treatment, if considered, should be aimed at reducing the risk of recurrence. Another possible reason for considering a treatment is the high parental anxiety in face of such a dramatic event (Baumer et al., 1981). Phenobarbital and sodium valproate have been shown to be effective in preventing recurrences of febrile convulsions (Wallace, 1980; Wolf, 1981) but both can produce serious side effects (Jeavons, 1982; Wolf, 1981). It also has been suggested that the long-term administration of phenobarbital in children could have detrimental effects on behavioural development and cognitive functions (Camfield et al., 1979; Hirtz, 1978). Intermittent treatment with diazepam given orally or by suppository has

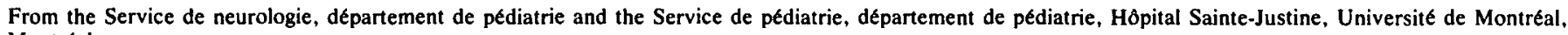
Montréal

Received February 23, 1984. Accepted in revised form May 29, 1984

Reprint requests to: Dr. Michel Vanasse, Laboratoire EEG-EMG, Hôpital Sainte-Justine. 3175, Cóte Ste-Catherine, Montréal, Québec, Canada H3T IC5 
been reported to be as effective as continuous treatment with phenobarbital, while limiting to a minimum the risk of side effects and toxicity (Dianese, 1979, 1980; Knudsen and Vestermark, 1978; Thorn, 1981). We conducted a study of the efficiency of nitrazepam given only when the children were febrile, in preventing recurrences of convulsions. We chose nitrazepam rather than diazepam because we had more experience with 'this drug (Vanasse and Geoffroy, 1978).

\section{Material AND METhodS}

One hundred and sixteen children took part in this study. They were referred from the emergency room of Hôpital SainteJustine after being seen for a febrile seizure not associated with an intracranial infection or a specific metabolic disease. Patients aged less than 3 months or more than 6 years, as well as those who showed epileptogenic activity on their EEG, were excluded.

The initial clinical and biological evaluation was done in the emergency room as previously described by one of us (Rollin and Masson, 1979). Children were then referred to the outpatient clinic and seen at least 10 days after the seizure. The evaluation included a detailed medical and family history, a pediatric and neurological examination, and an EEG. Children with epileptogenic activity on their EEG were excluded.

According to the age of the child and the type of seizures he had, patients were divided in two groups with regard to the risk of recurrence. As has been shown in previous clinical studies (Fishman, 1979; Lennox-Buchtal, 1974), the risk of recurrence is much higher in some children. From our own experience, we consider the following factors to contribute to a high risk of recurrence: less than 12 months of age at the first febrile convulsion; previous history of one or several febrile seizures; atypical convulsion (longer than 10 minutes; focal or complex or repetitive seizures).

After detailed explanations to parents about the relatively benign nature of febrile seizures and the treatment available for this condition, an intermittent prophylactic treatment with nitrazepam was suggested in children with a high risk of recurrence. Nitrazepam was to be given as soon as the fever $\left(\mathrm{T}^{\circ} \geqslant 38^{\circ} \mathrm{C}\right)$ was discovered and was continued until it had disappeared for at least 12 hours. The dose administered was 0.25 $0.5 \mathrm{mg} / \mathrm{kg} / 24$ hours, divided equally into 3 doses given orally every 8 hours.

In children with a low risk or recurrence, we recommended that no treatment be given.

\section{Follow-up}

Follow-up in these patients varied from a minimum of 12 months to 24 months (mean 15.4 months). They were contacted every six months and seen every twelve months. On each occasion, parents were asked about the number of febrile episodes their child experienced and if and how the medication was given during these episodes. Although this could have been useful in assessing the results, plasma determination or qualitative examination for nitrazepam were not done because we felt it was almost impossible to carry out such procedures in intermittently treated children.

\section{Results}

From the 116 patients seen initially, 10 were lost to follow-up. Of the remaining 106, 55 were considered as having a high risk of recurrence and 51 a low risk according to the above mentioned criteria.

\section{A. Children with a high risk of recurrence}

This group of 55 children can be divided in two: 31 children in whom parents agreed to administer nitrazepam and understood how it had to be given. There were 16 girls and 15 boys in this group. Every child had at least one episode of fever during the period of follow-up and the average number of febrile episodes in this group was 3.4. This is, however, only an estimation since it is based on a retrospective questionnaire. Recurrence was seen in 6 children (19.3\%) and in every one of them the convulsion occurred before the parents were aware of fever.

On the other hand, 19 parents initially or later decided not to use the medication. Five used it incorrectly: in two children, the parents gave nitrazepam after the convulsion because they thought it was intended to prevent the repetition of seizures; in three the drug was given only occasionally. Twenty-three of these children had at least one episode of fever and the average number of episodes was 2.9. This group included 13 boys and 11 girls and recurrence occurred in 11 children $(45.8 \%)$. Clinical data concerning this group of high risk patients are summarized in Table 1. The risk of recurrence is thus statistically lower in the treated group: $\mathrm{X}^{2}=4.45 \mathrm{p}<0.05$.

\section{B. Children with low risk of recurrence}

Fifty-one patients were included in this group. As we mentioned previously, we recommended that no treatment should be given to these children. Forty-five parents agreed with this recommendation while 6 still preferred that nitrazepam be given because of their fear of convulsions. None of these 6 children had a recurrence although all 6 had at least one episode of fever during the period of follow-up. Six (13.6\%) of the 45 untreated children had another seizure.

\begin{tabular}{|c|c|c|c|c|c|}
\hline & $\begin{array}{c}\text { Age at } \\
\text { First } \\
\text { Convulsion }\end{array}$ & \multicolumn{3}{|c|}{ Type of Seizures } & $\begin{array}{c}\text { Re- } \\
\text { currence }\end{array}$ \\
\hline & & Typical & $\begin{array}{l}\text { Atypical } \\
\text { (a) } \\
\end{array}$ & Recurrent & \\
\hline $\begin{array}{l}\text { Treated } \\
\text { with }\end{array}$ & $\begin{array}{l}<12 \text { mos. } \\
>12 \text { mos. }\end{array}$ & $3(1)$ & $\begin{array}{l}5(1) \\
4(1)\end{array}$ & $\begin{array}{c}3 \\
16(3)\end{array}$ & $\begin{array}{r}2 / 11 \\
4 / 20 \\
\end{array}$ \\
\hline Nitrazepam & & & & & $6 / 31(19.3 \%)$ \\
\hline \multirow{2}{*}{$\begin{array}{l}\text { Untreated } \\
\text { or } \\
\text { inadequately } \\
\text { treated }\end{array}$} & $\begin{array}{l}<12 \text { mos. } \\
>12 \text { mos. }\end{array}$ & $\begin{array}{l}7(1) \\
-\end{array}$ & $\overline{8(2)}$ & $\begin{array}{l}2(2) \\
7(6)\end{array}$ & $\begin{array}{l}3 / 9 \\
8 / 15 \\
\end{array}$ \\
\hline & & & & & $\begin{array}{c}11 / 24(45.8 \%) \\
p<0.005\end{array}$ \\
\hline
\end{tabular}

(a) Atypical seizures include long duration ( $\geqslant 10$ minutes), partial, complex or repetitive seizures.

Numbers in brackets indicate the number of children in each category who had another febrile seizure during the period of follow-up. 


\section{Side Effects}

Of the 46 children who received nitrazepam at least on one occasion, $15(32.6 \%)$ experienced side effects. In three, ataxia and drowsiness were seen and were severe enough to convince the parents to abandon the medication. These three children received the maximum dose of nitrazepam $(0.5 \mathrm{mgs} / \mathrm{kg} / 24$ hours $)$ and the reintroduction of nitrazepam at a lower dose in one of them (after he had another convulsion) did not produce any significant side-effects. In the remaining 12 children, side-effects were mild and did not bother the parents. They consisted of drowsiness in 9, agitation in 2, and ataxia and drowsiness in one.

\section{Discussion}

Intermittent treatment with diazepam orally and by suppository has been shown to be as effective as continuous treatment with phenobarbital in preventing recurrence of febrile seizures (Dianese, 1979, 1980; Knudsen and Vestermark, 1978; Thorn, 1981) and has the obvious advantage of limiting side-effects to a minimum. The results of our study with nitrazepam show that this drug used intermittently also is effective in preventing recurrence of febrile seizures in children at high risk. The rate of recurrence in these children was $19.3 \%$ while it was $45.8 \%$ in 24 untreated or inadequately treated children $\left(X^{2}=4.42 \mathrm{p} 0.05\right)$ also presenting a high risk of recurrence.

The rate of recurrence we observed may appear high as compared to what has been found in other studies in which this rate varied from 5 to $17 \%$ when children were treated either with phenobarbital or diazepam (Dianese, 1979, 1980; Knudson and Vestermark, 1978; Thorn, 1981; Wallace and Aldridge, 1980; Wolf, 1981). One must remember, however, that all the children we treated had a high risk of recurrence while these other studies included children with low as well as high risks of recurrence. Furthermore, in our study all treated children who had a recurrence, sustained it before fever was noticed and thus none of them could receive nitrazepam in time. It is possible that improved results could be obtained if the medication were given as soon as the premonitory signs of infection appear as suggested by Dianese (1980), rather than waiting for fever to appear.

Based on our results, we feel that nitrazepam given intermittently is an effective prophylactic treatment of febrile convulsions. Immediate side-effects are generally mild and the risk of toxicity and long-term behavioral or cognitive detrimental effects practically nonexistant. This treatment should be considered only in children with a high risk of recurrence as we defined it, since in other children, the risk of recurrence is low $(13.6 \%)$ and, in our opinion, does not justify treatment.

\section{ACKNOWLEDGEMENT}

The authors thank the pediatricians of the Emergency Room of Hôpital Sainte-Justine for their precious collaboration and Ms Françoise Bénard and Danielle Pelletier for their secretarial assistance.

This study was supported by the Savoy Foundation for epilepsy.

\section{REFERENCES}

Aicardi J, Chevrie JJ (1976) Febrile convulsions: neurological sequelae and mental retardation. In: Brazier MAB, Cocceani F. eds, Brain dysfunction in infantile febrile convulsions. Raven Press, New York: 247-257.

Baumer JH, David TJ, Valentine SJ, Roberts JE, Hughes BR (1981) Many parents think that their child is dying when having a first febrile convulsion. Dev. Med. Child. Neurol. 23: 462-464.

Camfield CS, Chaplin S, Doyle AB, Shapiro SH, Cummings C, Camfield PR (1979) Side effects of phenobarbital in toddlers: behavioral and cognitive aspect. J. Pediatr. 95: 361-365.

Dianese G (1979) Prophylactic diazepam in febrile convulsions. Arch. Dis. Child. 54: 244.

Dianese G (1980) Treatment of febrile seizures. J. Pediatr. 96: 516-517.

Ellenberg JH, Nelson KB (1978) Febrile seizures and later intellectual performance. Arch. Neurol. 35: 17-21.

Falconer MA (1976) Surgical treatment of sequelae of severe febrile convulsions. In: Brazier MAB, Cocceani F. eds, Brain dysfunction in infantile febrile convulsions. Raven Press, New York: 307-326.

Fishman MA (1979) Febrile seizures: The treatment controversy. J. Pediatr. 94: 177-184.

Hauser WA (1981) The natural history of febrile seizures. In: Nelson K.B., Ellenberg J.H. eds, Febrile seizures. Raven Press, New York: 5-17.

Hirtz DG (1981) Effects of treatment for prevention of febrile seizure recurrence on behavioral and cognitive function. $I n$ : Nelson K.B., Ellenberg J.H. eds, Febrile seizures. Raven Press, New York: 193-202.

Jeavons PM (1982) Valproate. Toxicity. In: Woodbury D.M., Penry J.K., Pippenger C.E., eds, Antiepileptic drugs (2nd ed) New York: Raven Press: 601-610.

Kendig EL, Dyken PR, Hernandez N, McKee M, Peterson HC, Richards NG, Shackelsford RH, Smith EE, Wilder BJ, Wittes J (1981) Consensus statement on febrile seizures. In: Nelson K. B., Ellenberg J.H., eds, Febrile seizures. Raven Press, New York: 301-306.

Knudsen FV, Vestermark S (1978) Prophylactic diazepam or phenobarbitone in febrile convulsions: a prospective, controlled study. Arch. Dis. Child. 53: 660-663.

Lennox-Buchtal MA (1974) Febrile convulsions. In: Vinken P.J., Bruyn G.W., eds, Handbook of Clinical Neurology, vol. 15, Amsterdam, North Holland: 246-263.

Moshe SL (1981) The kindling phenomenon and its possible relevance to febrile seizures. In: Nelson K.B., Ellenberg J.H. eds, Febrile seizures. Raven Press, New York: 59-63.

Rollin P, Masson P (1979) Evaluation de l'investigation des convulsions fébriles. Etude de 291 cas. Union Méd. Can. 108: 1465-1472.

Schiottz-Christensen E, Bruhn P (1973) Intelligence, behavior and scholastic achievement subsequent to febrile convulsions: an analysis of discordant twin pairs. Dev. Med. Child. Neurol. 15: 565-575.

Thorn J (1981) Prevention of recurrent febrile seizures: Intermittent prophylactic with diazepam compared with continuous treatment with phenobarbital. In: Nelson K.B., Ellengerg J.H., eds, Febrile seizures. Raven Press, New York: 119-126.

Vanucci RC (1981) Metabolic and pathological consequences of experimental febrile seizures and status epilepticus. In: Nelson K.B., Ellenberg J.H., eds, Febrile seizures. Raven Press, New York: 43-57.

Vanasse M, Geoffroy G (1978) Treatment of epilepsy in children with nitrazepam. Epilepsy International Symposium, Vancouver.

Wallace SJ, Cull AM (1979) Long-term psychological outlook for children whose first fit occurs with fever. Dev. Med. Child. Neurol. 21: $28-40$.

Wallace SJ, Aldridge Smith J (1980) Successful prophylaxis against febrile convulsions with valproic acid or phenobarbital. Br. Med. 1: 353-354.

Wolf SM (1981) Prevention of recurrent febrile seizures with continuous drug therapy: Efficacy and problems of phenobarbital or phenytoin therapy. In: Nelson K.B., Ellenberg J.H. Febrile seizures. Raven Press, New York: 127-134. 